\title{
The role of the lactate level in determining the risk rates of small bowel resection in incarcerated hernias
}

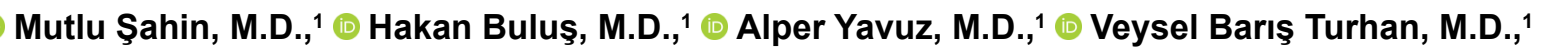

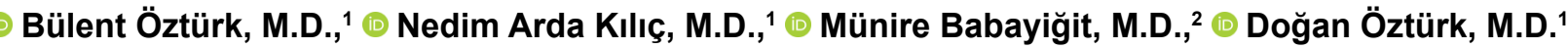

1'Department of General Surgery, Keçiören Training and Research Hospital, Ankara-Turkey

${ }^{2}$ Department of Anesthesiology and Reanimation, Keçiören Training and Research Hospital, Ankara-Turkey

\begin{abstract}
BACKGROUND: An incarcerated hernia is a part of the intestine or abdominal tissue that becomes trapped in the sac of a hernia. An increase in morbidity and mortality occurs after intestinal resections from strangulated hernias. This study aims to examine the markers that may be effective in determining the risk of small bowel resection due to incarcerated hernias. In particular, we aimed to investigate the effect $s$ of blood lactate levels in determining this risk.
\end{abstract}

METHODS: A cross-sectional retrospective study was designed. Patients, whose preoperative diagnosis were reported as incarcerated hernia and had essential information, were included in this study. They were divided into two groups according to whether they had resection or not. Age, gender, hernia type, hernia side, resection material, blood lactate level (BLL), white blood cell (WBC), neutrophil count (NE), lymphocyte count (LY), neutrophil/lymphocyte ratio (NLR), platelet count (PLT), lactate dehydrogenase (LDH), radiologic bowel obstruction sign and comorbidities were evaluated.

RESULTS: Sixty-seven patients were included in this study. It was observed that $16(23.9 \%)$ of these patients underwent small intestinal resection, $16(23.9 \%)$ had an omentum resection, while no resection was performed on $35(52.2 \%)$ patients. There was a statistically significant difference regarding radiologically intestinal obstruction $(p=0.00 \mathrm{I})$, hernia type $(p=0.005), B L L(p<0.00 \mathrm{I}), \mathrm{WBC}$, NLR and LDH values $(p<0.05)$. In incarcerated hernia patients with a lactate value $\geq 1.46 \mathrm{mg} / \mathrm{dL}$, sensitivity was observed to be $84.0 \%$ and specificity $86.0 \%(p<0.00 \mathrm{I})$.

CONCLUSION: In patients with a preliminary diagnosis of an incarcerated hernia, the risk of possible small bowel resection is the most important point in deciding for an operation. The presence of an intestinal obstruction in radiological examinations, and particularly the high levels of WBC, NLR, LDH and BLL, may indicate a necessity for possible small bowel resection. Concerning the risk associated with small bowel resection, blood lactate levels $\geq 1.46 \mathrm{mg} / \mathrm{dL}$ may be alerting.

Keywords: Hernia; lactate; small intestine.

\section{INTRODUCTION}

Hernia repair is one of the most common surgical procedures. Each type of hernia has a risk of developing incarceration, which is an emergency situation. An incarcerated hernia is a part of the intestine or abdominal tissue that becomes trapped in the sac of a hernia. The hernial sac and its contents cannot be reduced to the abdominal cavity (irreducible) with standard maneuvers. The need for small bowel resection in incarcer- ated hernias occur most frequently in femoral hernias. ${ }^{[1,2]}$ An increase in morbidity and mortality rates has been reported after intestinal resections from strangulated femoral hernias. ${ }^{[3]}$ Many studies have been carried out to determine the parameters, to predict whether there is intestinal necrosis due to incarceration, before deciding on surgery. Unfortunately, no marker has been found to fully identify intestinal necrosis.

Cite this article as: Şahin M, Buluş H, Yavuz A, Turhan VB, Öztürk B, Kılıç NA, et al. The role of the lactate level in determining the risk rates of small bowel resection in incarcerated hernias. Ulus Travma Acil Cerrahi Derg 2020;26:593-599.

Address for correspondence: Mutlu Şahin, M.D.

Keçiören Eğitim ve Araştırma Hastanesi, Genel Cerrahi Kliniği, 06280 Keçiören, Ankara, Turkey

Tel: +90 312 - 3569000 E-mail: drmutlu@gmail.com

Ulus Travma Acil Cerrahi Derg 2020;26(4):593-599 DOI: 10.14744/tjtes.2020.02500 Submitted: 16.04.2020 Accepted: 27.04.2020 Online: 18.06.2020

Copyright 2020 Turkish Association of Trauma and Emergency Surgery 
Lactate is the end product of anaerobic glycolysis. It is produced even in conditions where oxygen is sufficient in all tissues (skeletal muscle, brain, erythrocytes, kidneys) of the human body. The normal value of plasma lactate concentration is accepted as being $0.5-1.5 \mathrm{mmol} / \mathrm{L} .{ }^{[4]}$ However, in patients with a critical illness, values up to $2 \mathrm{mmol} / \mathrm{L}$ can be considered normal. ${ }^{[4]}$ It was first used as a prognostic tool by Broder and Weil ${ }^{[5]}$ in 1964 , showing that greater than $4 \mathrm{mmol} / \mathrm{L}$ of lactate was associated with poor results in shock patients.

Intestinal hypoxia may lead to anaerobic metabolism. More lactate reaches the liver through the portal vein. Intestinal bacteria metabolize glucose and carbohydrate into D-lactate. As D-lactate may be metabolized slowly by human Lactate dehydrogenase (LDH), it contributes to the formation of lactic acidosis. ${ }^{[6]}$ Therefore, if the arterial circulation of the intestinal segment is disturbed in incarcerated hernia, an increase in serum lactate level can be expected. The level of lactate in peripheral blood has been used as a possible marker for acute mesenteric ischemia (AMI). ${ }^{[7]}$

The present study aims to examine the markers that may be effective in determining the risk of small bowel resection due to incarcerated hernias in the literature. In particular, we aimed to investigate the effects of blood lactate levels in determining this risk.

\section{MATERIALS AND METHODS}

Ethical approval for this study was obtained from the Clinical Research Ethics Committee on 26.02.2020. A cross-sectional, retrospective study was designed by collecting data, examining patient files and computer records. Patients who were operated on between January 2014 and December 2019 at General Surgery Clinic and whose preoperative diagnosis was reported as incarcerated hernia were included in this study. Patients who did not fit the criteria for this study due to a lack of information in data form were excluded from this study. Patients included were primarily divided into two groups as follows: patients who had a resection due to strangulation and patients who did not have a resection but only had a hernia repair.

Patients were evaluated based on age, gender, hernia type, hernia side, resection material, blood lactate level (BLL), white blood cell (WBC), neutrophil count (NE), lymphocyte count (LY), neutrophil/lymphocyte ratio (NLR), platelet count (PLT), lactate dehydrogenase (LDH), radiologic bowel obstruction sign and comorbidities. The blood samples for BLL test were taken venously or arterially in the emergency room. We converted the results obtained from venous blood to arterial form with a special formula ${ }^{[8]}$ and used these results.

\section{Statistical Analysis}

Continuous variables, mean \pm standard deviation, categorical data were expressed as numbers and percentages. In the intergroup analysis of continuous variables, normality analyses were performed using the Kolmogorov-Smirnov Goodness of Fit Test. In the comparative analysis between two groups conforming to the normal distribution of continuous variables, $t$ test was used, for the comparative evaluations between three groups, the One Way ANOVA Test (Post-hoc: LSD) was used. Intergroup comparisons of variables not suitable for normal distribution were made using the Kruskal Wallis Test (Posthoc: Mann-Whitney U Test). For the comparison of categorical data, Chi-Square Test was used. The ROC Curve Analysis Test was used to determine the diagnostic cut-off values for lactate in patients with incarcerated hernia. Analyzes were performed using the IBM SPSS Package Program version 24.0 (IBM Corporation, Armonk, NY, USA). The level of statistical significance was accepted as being $\mathrm{P}<0.05$.

\section{RESULTS}

It was observed that over a six-year-period, 438 patients with a pre-diagnosis of incarcerated hernia were operated. Of these 438 patients, only a total of 67 patients who fit the criteria and whose relevant data were able to be obtained were included in this study (Fig. I). It was observed that 16 (23.9\%) of these patients underwent small intestinal resection, 16 (23.9\%) patients had an omentum resection, while no resection was performed on 35 (52.2\%) patients. Concerning patients with the comorbid disease, it was observed that there was almost no difference between the groups. Additional chronic diseases were detected in seven $(43.75 \%)$ of 16 patients who underwent small bowel resection and omentum resection, and in 15 $(42.85 \%)$ of 35 patients who did not undergo any resection.

No statistically significant difference was observed between cases with and without resection concerning age, gender and hernia region $(p>0.05)$ (Table I). In addition, it was observed that a resection due to femoral hernia was performed in nine $(69.23 \%)$ of 13 patients operated on under emergency conditions. A statistically significant difference was observed $(p=0.007)$ in comparisons made according to the resection status of patients with radiologically intestinal obstruction (Table I).

When the comparative analyses of resected tissue type were performed according to hernia type, $43.8 \%$ of the cases with

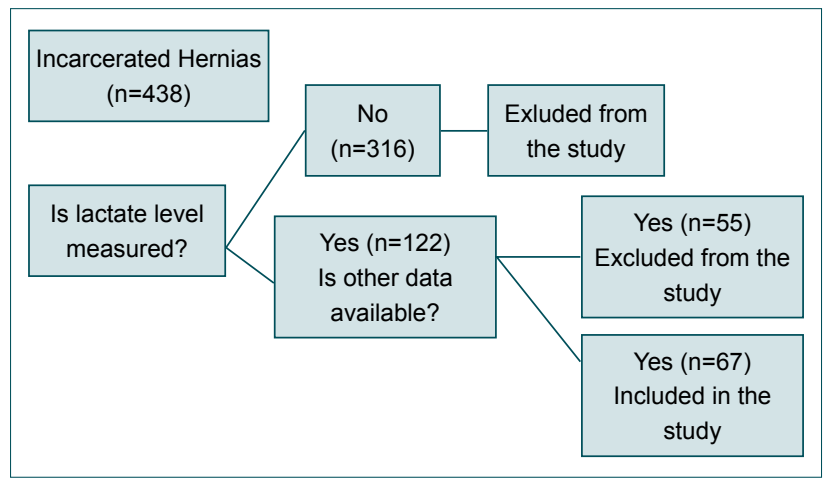

Figure 1. The process of including patients into this study. 
small bowel resection were observed to be inguinal, $25 \%$ femoral and $25 \%$ incisional hernia. It was found that $50.0 \%$ of cases with omentum resection were related to an umbilical hernia, and $54.3 \%$ of cases without resection were related to an inguinal hernia $(p=0.005)$ (Table 2$)$. In patients with radiologically detected intestinal obstruction, a highly statistically

Table I. Comparison of the diagnostic features of incarcerated hernia cases according to the presence of resection

\begin{tabular}{|c|c|c|c|c|}
\hline & With resection & Without resection & Total & $\mathbf{p}$ \\
\hline Age (years) $(\mathrm{Avg} \pm \mathrm{SD})$ & $61.63 \pm 14.13$ & $62.51 \pm 17.45$ & $62.7 \pm 15.93$ & $0.820^{*}$ \\
\hline \multicolumn{5}{|l|}{ Gender, n (\%) } \\
\hline Female & $21(65.6)$ & $17(48.6)$ & $38(56.7)$ & \multirow[t]{2}{*}{$0.159^{*}$} \\
\hline Male & II (34.4) & $18(51.4)$ & $29(43.3)$ & \\
\hline \multicolumn{5}{|l|}{ Hernia type, n (\%) } \\
\hline Inguinal & $8(25.0)$ & $19(54.3)$ & $27(40.3)$ & \multirow[t]{4}{*}{$0.057^{*}$} \\
\hline Femoral & $9(28.1)$ & $4(11.4)$ & $13(19.4)$ & \\
\hline Umbilical & $9(28.1)$ & $5(14.3)$ & $14(20.9)$ & \\
\hline Incisional & $6(18.8)$ & $7(20.0)$ & $13(19.4)$ & \\
\hline \multicolumn{5}{|l|}{ Side, n (\%) } \\
\hline Right & $7(21.9)$ & $12(34.3)$ & $19(28.4)$ & \multirow[t]{3}{*}{$0.37 I^{*}$} \\
\hline Left & $10(31.3)$ & $12(34.3)$ & $22(32.8)$ & \\
\hline Without any side & $15(46.9)$ & II (3I.4) & $26(38.8)$ & \\
\hline \multicolumn{5}{|c|}{ Bowel obstruction, n (\%) } \\
\hline Present & 23 (7I.9) & $13(37.1)$ & $36(53.7)$ & \multirow[t]{2}{*}{$0.007^{*}$} \\
\hline Not present & $9(28.1)$ & $22(62.9)$ & $31(46.3)$ & \\
\hline Total & $32(100)$ & $35(100)$ & $67(100)$ & \\
\hline
\end{tabular}

"T Test; "

Table 2. Comparison of the diagnostic features of incarcerated hernia cases. according to the type of resected tissue

\begin{tabular}{|c|c|c|c|c|c|}
\hline & Small bowel resection & Omentum resection & No resection & Total & $\mathbf{p}$ \\
\hline Age (years) (Avg \pm SD) & $64.25 \pm 13.43$ & $59.00 \pm 14.75$ & $62.51 \pm 17.45$ & $62.7 \pm 15.93$ & $0.635^{*}$ \\
\hline \multicolumn{6}{|l|}{ Gender, n (\%) } \\
\hline Female & $8(50.0)$ & $13(81.3)$ & $17(48.6)$ & $38(56.7)$ & $0.076^{* *}$ \\
\hline Male & $8(50.0)$ & $3(18.7)$ & $18(5 \mid .4)$ & $29(43.3)$ & \\
\hline \multicolumn{6}{|l|}{ Hernia type, n (\%) } \\
\hline Inguinal & $7(43.8)$ & I (6.3) & $19(54.3)$ & $27(40.3)$ & $0.005^{* *}$ \\
\hline Femoral & $4(25.0)$ & $5(3 \mid .3)$ & $4(11.4)$ & $13(19.4)$ & \\
\hline Umbilical & $\mathrm{I}(6.8)$ & $8(50.0)$ & $5(14.3)$ & 14 (20.9) & \\
\hline Incisional & $4(25.0)$ & $2(12.5)$ & $7(20.0)$ & $13(19.4)$ & \\
\hline \multicolumn{6}{|l|}{ Side, n (\%) } \\
\hline Right & $3(18.8)$ & $4(25.0)$ & $12(34.3)$ & $19(28.4)$ & $0.110^{* *}$ \\
\hline Left & $8(50.0)$ & $2(12.5)$ & $12(34.3)$ & $22(32.8)$ & \\
\hline Without any side & $5(31.2)$ & $10(62.5)$ & II (3I.4) & $26(38.8)$ & \\
\hline \multicolumn{6}{|l|}{ Bowel obstruction } \\
\hline Yes & 15 (93.8) & $8(50.0)$ & $13(37.1)$ & $36(53.7)$ & $0.00 I^{* *}$ \\
\hline No & I (6.3) & $8(50.0)$ & $22(62.9)$ & $31(46.3)$ & \\
\hline Total & $16(100)$ & $16(100)$ & $35(100)$ & $67(100)$ & \\
\hline
\end{tabular}

"No Way ANOVA Test, " Chi-square Test. SD: Standard deviation. 
Table 3. Comparison of some of the diagnostic features of the incarcerated hernia cases, according to resection status

\begin{tabular}{|c|c|c|c|c|}
\hline & Small bowel resection & Omentum resection & No resection & $\mathbf{p}$ \\
\hline Lactate $(\mathrm{mg} / \mathrm{dL})$ & $2.17 \pm 0.90^{*}$ & $1.695 \pm 0.48^{*}$ & $0.98 \pm 0.58^{*}$ & $<0.001^{*}$ \\
\hline White blood cell $\left(10^{3} / \mu \mathrm{L}\right)$ & $|5.65 \pm 4.6|^{*}$ & $10.34 \pm 4.09$ & $9.23 \pm 2.90^{*}$ & $<0.00 I^{* *}$ \\
\hline Neutrophil $\left(10^{3} / \mu \mathrm{L}\right)$ & $12.72 \pm 5.12^{*}$ & $8.29 \pm 3.21^{*}$ & $6.59 \pm 3.06^{*}$ & $<0.001^{*}$ \\
\hline Neutrophil/lymphocyte ratio & $9.84 \pm 10.79^{*}$ & $5.16 \pm 3.69$ & $4.64 \pm 3.62^{*}$ & $0.031^{*}$ \\
\hline Platelet count $\left(10^{3} / \mu \mathrm{L}\right)$ & $327.12 \pm 84.4 I^{*}$ & $254.86 \pm 105.60^{*}$ & $248.17 \pm 64.9 I^{*}$ & $0.006^{* *}$ \\
\hline Lactate dehydrogenase (IU/L) & $274.06 \pm 107.65^{*}$ & $254.56 \pm 62.09$ & $211.74 \pm 52.38^{*}$ & $0.003^{*}$ \\
\hline
\end{tabular}

"Kruskal Wallis Test (Post hoc: Mann-Whitney U Test), "* One Way ANOVA Test (Post hoc: LSD).

Table 4. AUC and cut-off values of lactate as an indicator for incarcerated hernia patients

\begin{tabular}{|c|c|c|c|c|c|c|c|c|}
\hline & \multicolumn{5}{|c|}{ Diagnostic test } & \multicolumn{2}{|c|}{ ROC curve } & \multirow[t]{2}{*}{$\mathbf{p}$} \\
\hline & Cut-off (mg/dL) & Sensitivity (\%) & Specificity (\%) & PPV & NPV & AUC & $95 \% \mathrm{Cl}$ & \\
\hline Lactate & $\geq 1.46$ & 84.00 & 86.00 & 47.80 & 52.20 & 0.86 & $0.772-0.965$ & $<0.001^{* *}$ \\
\hline
\end{tabular}

significant difference was observed in the comparison made according to the type of tissue resected $(p=0.00 \mathrm{I})$ (Table 2$)$.

BLL was found to be highly statistically significant $(p<0.00 \mathrm{I})$ in cases having undergone small bowel resection $(2.17 \pm 0.90$ $\mathrm{mg} / \mathrm{dL}$ ) and omentum resection $(1.695 \pm 0.48 \mathrm{mg} / \mathrm{dL})$, when compared to cases without resection $(0.98 \pm 0.58 \mathrm{mg} / \mathrm{dL})$. Neutrophil and PLT values were also found to be highly statistically significant in those with the small intestine and

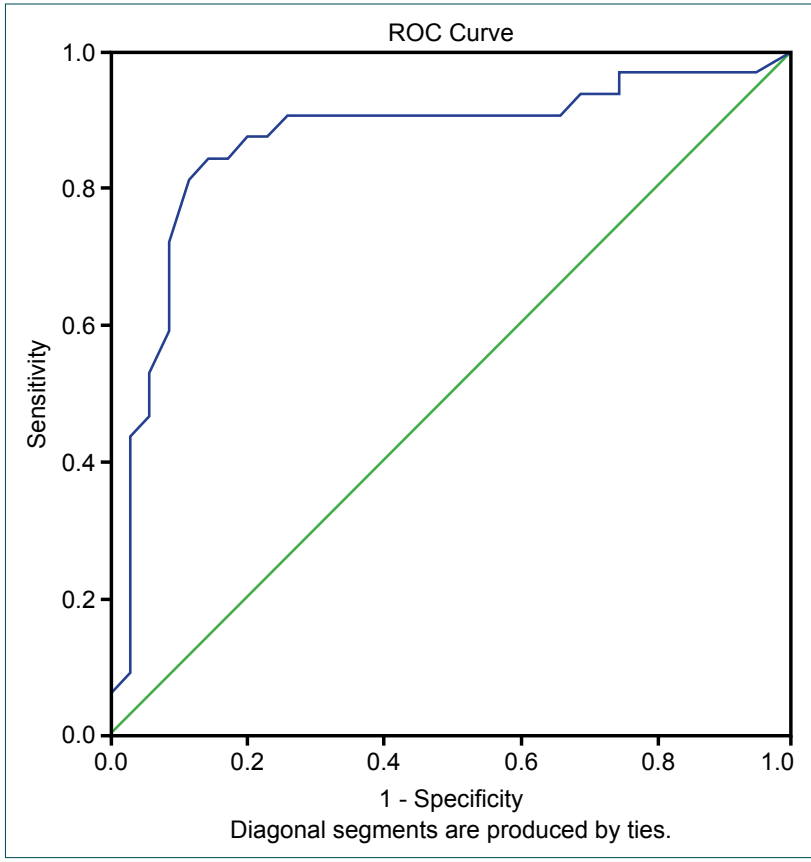

Figure 2. ROC curve of the lactate levels in incarcerated hernias. omentum resection, compared to the patients who did not undergo resection $(p<0.05)$. WBC, NLR and LDH values, between those who underwent small intestinal resection and those who were with no resection, were observed to lead to a significant difference $(p<0.05)$ (Table 3$)$.

In incarcerated hernia patients with a lactate value $\geq 1.46 \mathrm{mg} /$ $\mathrm{dL}$, sensitivity was observed to be $84.0 \%$, specificity $86.0 \%$, area under the ROC curve (Fig. 2) \pm standard error (AUC \pm $\mathrm{SE})=0.86 \pm 0.049(p<0.001)($ Table 4$)$.

\section{DISCUSSION}

Approximately $10 \%$ of the population develops some type of hernia during their lifetime. ${ }^{[9]}$ In the United States, more than I million abdominal hernia repairs are performed each year. ${ }^{[10]}$ Almost $75 \%$ of all hernias are inguinal with a rightside predominance, approximately $14 \%$ are umbilical, nearly $10 \%$ of hernias are incisional or ventral and only $3-5 \%$ of hernias are femoral. ${ }^{[1,12]}$ Hernia is the second most common cause of small intestinal obstructions, and almost $5 \%$ of all patients operated on for this condition, undergo emergency exploration. ${ }^{[1]}$

Currently, there is no medical consensus on a marker which preoperatively demonstrates if urgent bowel resection should be performed on a patient, who has developed an incarcerated hernia. In different research studies on this subject, various parameters have been presented. One of the most important of these is undoubtedly the type of hernia. In incarceration cases secondary to femoral hernia, the rate of urgent small bowel resection requirement due to necro- 
sis is approximately $45 \%$ and this is higher than for other types of hernia. ${ }^{[13-15]}$ There was not any statistical significance found between femoral hernia and resection due to incarceration, in this study. However, it was observed that nine of I 3 patients $(69.23 \%)$ underwent resection and four patients $(30.76 \%)$ underwent small bowel resection. These high rates indicate that the results are similar to other studies. In this study, there was no statistically significant result found in the evaluation made according to the type of hernia and the measurement made according to the presence of resection (Table I). In femoral and umbilical hernias, it was observed that proportionally more resections were performed. However, there was no statistically significant difference.

Regarding resected tissue type, the findings obtained in this study showed that there was a significant difference between hernia type and resected tissue type (Table 2). It was observed that whilst omentum resection was frequently performed on umbilical hernias in emergency surgery, small bowel resection had to be applied more frequently in strangulations that occur through a narrow channel such as femoral and inguinal hernia.

Apart from this, there are studies showing that there is an increased risk of small bowel resection in patients who are of female gender, ${ }^{[14-16]}$ are of advanced age $(>65),{ }^{[14,17]}$ have a long duration of incarceration, ${ }^{[15,18-20]}$ presence of bowel obstruction, ${ }^{[15,18,19]}$ and an apparent peritonitis tableux. ${ }^{[15]}$ Unlike in the studies mentioned above, in this study, it was observed that female gender and older age do not increase the risk of bowel resection.

There was no difference between the resection applied to the patient, and whether the hernia was on the right or left side of the patient. Due to insufficient data, it was not possible to evaluate the long duration of incarceration. However, in cases of bowel obstruction defined by radiological imaging methods, significant results were obtained, in parallel with the mentioned studies above. It was observed that in 15 of 16 patients requiring small bowel resection, diagnoses of bowel obstruction was made radiologically.

When we looked at from the perspective of laboratory diagnostic methods, there are studies that assert that increased WBC count, ${ }^{[15,18-20]}$ increased neutrophil count ${ }^{[15,20]}$ and increased NLR ratio, ${ }^{[18]}$ increase the risk of small bowel resection. In all of these studies, comparisons were made according to whether there was a small bowel resection or not. In this study, the presence of small intestine or omentum resection and the cases without any resection were compared.

Xie et al. ${ }^{[8]}$ reported that NLR ratios can serve as a biomarker for the prediction of severity of incarcerated hernias. When the data of our study were evaluated, it was found that there was a significant difference in WBC and NLR ratios, similar to this study. In addition, LDH values were significantly differ- ent, between patients who underwent small bowel resection and those who did not. However, in patients with omentum resection, WBC, NLR and LDH values had not increased significantly, compared to the non-resection group. In contrast, neutrophil and PLT values were found to be statistically significantly higher in patients with small intestine and omentum resection compared to patients without resection. According to these results, it is possible to say that the increase in WBC, NLR and LDH levels may be the early precursors of small bowel necrosis.

Approximately $1300 \mathrm{mmoL}$ of lactate is produced in the human body in a day. A large portion of this lactate (65-70\%) is metabolized by the liver and approximately $30-35 \%$ by extrahepatic tissues (kidney, heart, skeletal muscle, diaphragm). Human metabolism generally tries to balance the lactate level at below $1.0 \mathrm{mmol} / \mathrm{L}$. However, in cases where oxygen reaching the tissues is insufficient, serum lactate level is found high. This is frequently observed where volume loss due to trauma or bleeding, excessive dehydration, septic shock, severe anemia, and severe hypoxemia has occurred. Another important reason is the increased oxygen need of tissues. These are the situations as hyperthermia, tremors, seizures or extreme exercise.

The final important reason may be an insufficient use of oxygen in tissues. Intestinal hypoxia due to incarcerated hernia is a good example of this. D-Lactate level may increase in some clinical conditions, such as decreased colon motility, short bowel syndrome, jejunoileal by-pass, bacterial infections (Lactobacillus). ${ }^{[21]}$ In other words, the increase in lactate level may be a result of the growth of intestinal bacteria due to intestinal obstruction developed after incarceration. In addition, elevated lactate may permit an early suspicion, and thus influence the clinical decision-making with regard to prioritization of surgery in patients with acute mesenteric ischemia. ${ }^{[22]}$ As can be understood here, an increase in blood lactate level (BLL) may be an early stimulating marker, when small bowel arterial nutrition is disrupted.

In the literature, to our knowledge, there is no study investigating the lactate level in incarcerated hernias. Thus, this is the first study to investigate lactate values in incarcerated hernias, patients undergoing small bowel or omentum resection. According to the results of this study, lactate levels are higher in patients who underwent small bowel or omentum resection compared to patients without resection. This increase has been observed to be higher especially in patients with small bowel resection. In incarcerated hernia patients, the cut-off value of lactate was determined as $\geq 1.46$. Lactate levels above this value may be a warning that small bowel ischemia may be present.

The correlation between venous and arterial lactate levels is low. However, if venous lactate levels are normal, arterial lactate amounts are also very likely to be found at normal values. 
In cases indicating a need for lactate measurement, a venous blood sample may be an initial preference. ${ }^{[23]}$ In this study, generally preferred lactate measurement was made through venous blood. The formula developed by Mikami et al. ${ }^{[8]}$ was used in the regulation and calculation of the lactate levels obtained from these venous blood samples. With the help of this formula, the sample from venous blood was sufficient and it was not necessary to retake arterial blood to determine lactate values.

Arterial lactate level $=(-0.259)+$ Venous lactate level $\mathrm{x}$ (0.996).

As Kulah et al. ${ }^{[I]}$ have stated, correct timing is very important when deciding to operate because there is an increase in the mortality rates of patients with advanced age and serious additional diseases, after hernia repair. Patients should not be operated on in emergency conditions unless necessary. They should be carefully prepared in the pre-operative period and should be closely monitored during and after the operation. According to the available data, it is decided whether the patient will undertake a vital operation or not.

It is appreciated that, the greatest weakness in this study was the low number of patients. Even though 438 patients were actually operated on over a period of six years, the data required for the purpose of this study could only be obtained for 67 patients. Although this appears to have caused some minor imbalances in the groups we created in this study, it is thought that statistically significant results were obtained.

\section{Conclusion}

In patients with a preliminary diagnosis of an incarcerated hernia, the risk of possible small bowel resection is the most important point in deciding for an operation. It was observed that during preoperative evaluation, the presence of intestinal obstruction in radiological examinations, and particularly the high levels of WBC, NLR, LDH and serum lactate values detected in laboratory tests, may suggest a necessity for possible small bowel resection. Concerning the risks associated with small bowel resection, blood lactate levels $\geq 1.46 \mathrm{mg} /$ $\mathrm{dL}$ may be alerting. To investigate this subject, prospective randomized studies with large series are needed.

Ethics Committee Approval: Approved by the local ethics committee.

Peer-review: Internally peer-reviewed.

Authorship Contributions: Concept: M.Ş.; Design: M.Ş., N.A.K.; Supervision: H.B.; Materials: A.Y., V.B.T., B.Ö., D.Ö., M.B.; Data: N.A.K.; Analysis: M.B.; Literature search: M.Ş.; Writing: M.Ş.; Critical revision: H.B.

Conflict of Interest: None declared.

Financial Disclosure: The authors declared that this study has received no financial support.

\section{REFERENCES}

1. Kulah B, Kulacoglu IH, Oruc MT, Duzgun AP, Moran M, Ozmen MM, et al. Presentation and outcome of incarcerated external hernias in adults. Am J Surg 2001;181:101-4. [CrossRef]

2. Kurt N, Oncel M, Ozkan Z, Bingul S. Risk and outcome of bowel resection in patients with incarcerated groin hernias: retrospective study. World J Surg 2003;27:741-3. [CrossRef]

3. Dahlstrand U, Wollert S, Nordin P, Sandblom G, Gunnarsson U. Emergency femoral hernia repair: a study based on a national register. Ann Surg 2009;249:672-6. [CrossRef]

4. Mizock BA, Falk JL. Lactic acidosis in critical illness. Crit Care Med 1992;20:80-93. [CrossRef]

5. Broder G., Weil MH. Excess Lactate: An index of reversibility of shock in human patients. Science 1964;143:1457-9. [CrossRef]

6. Rixen D, Siegel J. Bench-to-bedside review: oxygen debt and its metabolic correlates as quantifiers of the severity of hemorrhagic and posttraumatic shock. Critical Care 2005;9:441-53. [CrossRef]

7. Demir IE, Ceyhan GO, Friess H. Beyond lactate: is there a role for serum lactate measurement in diagnosing acute mesenteric ischemia? Digestive Surgery 2012;29:226-35. [CrossRef]

8. Mikami A, Ohde S, Deshpande GA, Mochizuki T, Otani N, Ishimatsu S. Can we predict arterial lactate from venous lactate in the ED?. Am J Emerg Med 2013;31:1118-20. [CrossRef]

9. Ruhl CE, Everhart JE. Risk factors for inguinal hernia among adults in the US population. Am J Epidemiol 2007;165:1154-61. [CrossRef]

10. Fitch MT, Manthey DE. Abdominal hernia reduction. In: Roberts and Hedges' Clinical Procedures in Emergency Medicine. Roberts JR, Custalow CB, Thomsen TW, editors. 6th ed. Philadelphia: Elsevier Saunders; 2014.p.873-9.

11. Katz DA. Evaluation and management of inguinal and umbilical hernias. Pediatr Ann 2001;30:729-35. [CrossRef]

12. Matthews RD, Neumayer L. Inguinal hernia in the 21 st century: an evidence-based review. Curr Probl Surg 2008;45:261-312. [CrossRef]

13. Gallegos NC, Dawson J, Jarvis M, Hobsley M. Risk of strangulation in groin hernias. Br J Surg 1991;78:1171-3. [CrossRef]

14. Alvarez Pérez JA, Baldonedo RF, Bear IG, Solís JA, Alvarez P, Jorge JI. Emergency hernia repairs in elderly patients. Int Surg 2003;88:231-7.

15. Ge BJ, Huang Q, Liu LM, Bian HP, Fan YZ. Risk factors for bowel resection and outcome in patients with incarcerated groin hernias. Hernia 2010;14:259-64. [CrossRef]

16. Tatar C, Tüzün İS, Karşıdağ T, Kızılkaya MC, Yılmaz E. Prosthetic Mesh Repair for Incarcerated Inguinal Hernia. Balkan Med J 2016;33:434-40.

17. Atila K, Guler S, Inal A, Sokmen S, Karademir S, Bora S. Prosthetic repair of acutely incarcerated groin hernias: a prospective clinical observational cohort study. Langenbecks Arch Surg 2010;395:563-8. [CrossRef]

18. Xie X, Feng S, Tang Z, Chen L, Huang Y, Yang X. Neutrophil-to-Lymphocyte Ratio Predicts the Severity of Incarcerated Groin Hernia. Med Sci Monit 2017;23:5558-63. [CrossRef]

19. Koizumi M, Sata N, Kaneda Y, Endo K, Sasanuma H, Sakuma Y, et al. Optimal timeline for emergency surgery in patients with strangulated groin hernias. Hernia 2014;18:845-8. [CrossRef]

20. Chen P, Huang L, Yang W, He D, Liu X, Wang Y, et al. Risk factors for bowel resection among patients with incarcerated groin hernias: A metaanalysis. Am J Emerg Med 2020;38:376-83. [CrossRef]

21. Zhang DL, Jiang ZW, Jiang J, Cao B, Li JS. D-lactic acidosis secondary to short bowel syndrome. Postgrad Med J 2003;79:110-2. [CrossRef]

22. Ambe PC, Kang K, Papadakis M, Zirngibl H. Can the Preoperative 
Serum Lactate Level Predict the Extent of Bowel Ischemia in Patients Presenting to the Emergency Department with Acute Mesenteric Ischemia?. Biomed Res Int 2017;2017:8038796. [CrossRef]
23. Bloom B, Pott J, Freund Y, Grundlingh J, Harris T. The agreement between abnormal venous lactate and arterial lactate in the ED: a retrospective chart review. Am J Emerg Med 2014;32:596-600. [CrossRef]

\section{ORIJIINAL ÇALIŞMA - ÖZET}

\section{İnkarsere hernilerde ince bağırsak rezeksiyonu risk oranlarını saptamada laktat düzeyinin rolü}

Dr. Mutlu Şahin, ${ }^{1}$ Dr. Hakan Buluş, ${ }^{1}$ Dr. Alper Yavuz, ${ }^{1}$ Dr. Veysel Barış Turhan, ${ }^{1}$ Dr. Bülent Öztürk, ${ }^{1}$ Dr. Nedim Arda Kılıç, ${ }^{1}$ Dr. Münire Babayiğit, ${ }^{2}$ Dr. Doğan Öztürk ${ }^{1}$

${ }^{1}$ Keçiören Eğitim ve Araştırma Hastanesi, Genel Cerrahi Kliniği, Ankara

${ }^{2}$ Keçiören Eğitim ve Araştırma Hastanesi, Anesteziyoloji ve Reanimasyon Kliniği, Ankara

AMAÇ: İnkarsere fitık, bağırsakların veya başka bir abdominal dokunun fitık kesesi içerisinde sıkışması ile oluşur. Boğulmuş fitıklardan gelen bağırsak rezeksiyonlarından sonra morbidite ve mortalitede bir artış meydana gelir. Bu çalışmanın amacı, inkarsere fitıklardan dolayı ince bağırsak rezeksiyonu riskini belirlemede etkili olabilecek belirteçleri incelemektir. Bu riski belirlemede, özellikle kan laktat düzeylerinin etkisini araştırmayı amaçladık. GEREÇ VE YÖNTEM: Kesitsel, geriye dönük bir çalışma tasarlandı. Ameliyat öncesi tanısı hapsedilmiş fitık olarak bildirilen ve gerekli bilgileri olan hastalar çalışmaya dahil edildi. Rezeksiyona sahip olup olmadıklarına göre iki gruba ayrıldı. Yaş, cinsiyet, fıtık tipi, fitık tarafı, rezeksiyon materyali, kan laktat seviyesi (BLL), beyaz kan hücresi (WBC), nötrofil sayısı (NE), lenfosit sayısı (LY), nötrofil/lenfosit oranı (NLR), trombosit sayısı (PLT), laktat dehidrojenaz (LDH), radyolojik bağırsak tıkanıklığı işareti ve komorbiditeler değerlendirildi.

BULGULAR: Il|gili verileri elde edilebilen 67 hasta çalışmaya dahil edildi. Bu hastaların I6'sında (\%23.9) ince bağırsak rezeksiyonu, 16'sında (\%23.9) omentum rezeksiyonu, 35 'inde (\%52.2) rezeksiyon yapılmadığı görüldü. Radyolojik olarak bağırsak tıkanıklığı $(p=0.00 \mathrm{I})$, fitık tipi $(p=0.005), B L L$ $(p<0.00 \mathrm{I}), \mathrm{WBC}, \mathrm{NLR}$ ve LDH değerleri $(p<0.05)$ arasında istatistiksel olarak anlamlı fark vardı. Laktat değeri $\geq 1.46 \mathrm{mg} / \mathrm{dL}$ olan hapsedilmiş fıtık hastalarında duyarlılık \%84.0 ve özgüllük \%86.0 olarak gözlendi $(p<0.001)$.

TARTIŞMA: İnkarsere fitık ön tanısı olan hastalarda, olası ince bağırsak rezeksiyonu riski, bir operasyona karar vermede en önemli noktadır. Radyolojik incelemelerde bağırsak tıkanıklığııı varlığı ve özellikle yüksek WBC, NLR, LDH ve BLL seviyeleri, olası ince bağırsak rezeksiyonu için bir gerekliliği gösterebilir. İnce bağırsak rezeksiyonu ile ilişkili risk açısından, $\geq 1.46 \mathrm{mg} / \mathrm{dL}$ kan laktat seviyeleri uyarıı olabilir.

Anahtar sözcükler: Fitık; ince bağırsak; laktat.

Ulus Travma Acil Cerrahi Derg 2020;26(4):593-599 doi: 10.14744/tjtes.2020.02500 